\title{
Fabrício Corsaletti
}

\section{Como você pensa a relação entre o tempo literá- rio e o tempo histórico?}

Você quer saber de que maneira a história aparece no que escrevo? É provável que de várias maneiras, às vezes mais explicitamente, às vezes implicitamente. Aos vinte anos eu achava que a ligação entre arte e vida era mais direta, e talvez fosse mesmo. Eu sabia, ou pensava que sabia, de onde os poemas nasciam. Agora a coisa complicou um pouco. Escrevo sobre algo que não sei bem o que é, o resultado é diferente do que num primeiro momento imaginei e no fim acabo aceitando que não sei do que trata o poema. Em geral, tenho as minhas interpretações; mas não me convencem tanto quanto antes. Por isso não sei como a história entra no que escrevo. A sensação é de que tudo o que escrevo está colado à história. Mas não posso garantir que seja assim.

\section{Quais procedimentos sua obra adota diante de} um mundo em que predominam a ação econômica e a espetacularização da arte?

Acredito que a arte tem a função de transformar o homem, de libertá-lo e em certo sentido vingá-lo das injustiças causadas por esse mundo "em que predominam a ação econômica e a espetacularização da arte" ou por outro qualquer. Pessoalmente, sinto tanto prazer em terminar um poema que, por alguns instantes, todo o resto se torna secundário. Gosto da ideia do Alfredo Bosi - a poesia como resistência - e também da do Augusto de Campos - a poesia como recusa. Quanto aos procedimentos, não sei. Tento apenas ser honesto comigo mesmo.

\section{Qual reflexão sua obra produz sobre a tradição} literária brasileira?

Em primeiro lugar, acho que quem tem que responder isso não sou eu, mas um crítico interessado no que faço. Por outro lado, a pergunta pressupõe um projeto e não tenho um "projeto literário". Quem tinha projeto era o Mário de Andrade, o Oswald. Não acredito que todo escritor tenha um plano da obra a ser realizada. Qual era o plano do Dylan Thomas além do de ser poeta?

\section{Como você pensa a forma literária?}

Desconfio que a forma literária seja uma mistura de vozes familiares, vozes das ruas, vozes de outros autores e alguma coisa que não é nada disso. Conscientemente, só sei que tento ser direto e conciso, e fiel à minha intuição, embora eu saiba que a intuição é também uma construção. Mas não é apenas construção. Outra coisa é que cada vez fica mais claro para mim que não é o poeta que "pensa a forma". Ele ajuda a forma a se pensar. É como se você acabasse virando um serviçal de si mesmo, quer dizer, daquele outro de que falava o Rimbaud.

Fabrício Corsaletti (1978) é autor de Estudos para o seu corpo (Companhia das Letras, 2007), King Kong e cervejas (Companhia das Letras, 2008), Golpe de ar (Editora 34, 2009) e Esquimó (Companhia das Letras, 2010). 